\title{
Composições possíveis: travessias no pluriverso dos encontros com a surdez
}

\author{
Composiciones posibles: travesías en el \\ pluriverso de los encuentros con la sordera
}

\section{Possible compositions: crossing the pluriverse of encounters with deafness}

\author{
Lucila Lima da Silva \\ ORCID ID: 0000-0001-7320-9188 \\ Universidade Federal Fluminense (UFF), Brasil \\ Marcia Moraes \\ ORCID ID: 0000-0002-8581-6126 \\ Universidade Federal Fluminense (UFF), Brasil \\ Autor referente: mazamoraes@gmail.com \\ Historia editorial \\ Recibido: 13/02/2019 \\ Aceptado: 14/10/2019
}

\section{RESUMO}

Este artigo tem o objetivo de colocar em xeque a oposição binária que separa surdos e ouvintes, como se fossem dois mundos distintos, cada qual marcado com sua própria cultura e língua: a língua brasileira de sinais em oposição ao português. Partindo de uma metodologia que se baseia de um lado, nos encontros mistos entre surdos e ouvintes (Martins, 2006) e, de outro lado, na narrativa de histórias do cotidiano, 0 texto indica que 0 binarismo não nos leva ao encontro da diferença. Assim, o trabalho conclui indicando que a tradução como versão, tal como proposta por Despret, (2012), é um modo de compor um mundo comum não como um universo, mas como pluriverso (Latour, 2011). A composição do comum como pluriverso é uma ação cotidiana, é também uma aposta ética e política a ser ativada reiteradamente no encontro com a diferença.

Palavras-chave: Surdos; ouvintes; mundo comum; pluriverso 


\section{RESUMEN}

Este artículo tiene como objetivo poner en tela de juicio la oposición binaria que separa sordos y oyentes, como si fueran dos mundos diferentes, cada uno marcado con su propia cultura y lengua: la lengua de signos de Brasil en comparación con el portugués. A partir de una metodología que se basa en un lado, en los encuentros mixtos entre sordos y oyentes (Martins, 2006) $y$, por otro lado, en la narrativa de historias de lo cotidiano, el texto indica que el binarismo no nos lleva al encuentro de la diferencia. Así, el trabajo concluía indicando que la traducción como versión, tal como propone Despret (2012), es un modo de componer un mundo común no como un universo, sino como pluriverso (Latour, 2011). La composición de lo común como pluriverso es una acción cotidiana, es también una apuesta ética y política a ser activada repetidamente en el encuentro con la diferencia.

Palabras clave: Sordos; oyentes; mundo común; pluriverso

\section{ABSTRACT}

This article aims to put in check the binary opposition that separates deaf and hearing, as if they were two distinct worlds, each marked with its own culture and language: the Brazilian language of signs as opposed to Portuguese. From a methodology based on the one hand, in the mixed meetings between deaf and listeners (Martins, 2006) and, on the other hand, in the narrative of everyday stories, the text indicates that binarism does not lead us to encounter difference. Thus, the paper concludes by pointing out that translation as a version, as proposed by Despret (2012), is a way of composing an common world not as a universe, but as pluriverse (Latour, 2011). The composition of the common as pluriverse is an everyday action, it is also an ethical and political bet to be activated repeatedly in the encounter with the difference.

Keywords: Deaf; listeners; common world; pluriverse

$\mathrm{O}$ artigo que ora escrevemos é fruto da dissertação de mestrado de uma das autoras e tem como questão central problematizar uma polarização que perpassa o senso comum e também alguns cenários no campo da surdez: a radical distinção entre o mundo dos surdos e o mundo dos ouvintes. A questão linguística parece ser um marcador relevante nessa oposição quando pensamos nos surdos usuários da Língua Brasileira de Sinais, a Libras, e nos ouvintes usuários do 
português. Tal oposição binária é recorrente em muitos espaços em que circulamos, especialmente naquele voltado para a educação da pessoa surda.

As duas autoras que assinam esse trabalho, diante deste campo, percebem-se marcadas como pessoas ouvintes. Uma de nós atua como psicóloga em uma instituição de educação de surdos situada na cidade do Rio de Janeiro e foi nesse espaço que a questão da pesquisa foi sendo formulada: qual é o lugar de uma pessoa ouvinte numa instituição de educação de surdos? Como articular as relações entre surdos e ouvintes?

No percurso de elaboração da pesquisa de mestrado que resultou nesse artigo, fomos nos dando conta de que a marcação dos mundos surdo e ouvinte como dois polos separados empobrece e reduz as possibilidades de articulação com as diferenças. Nesta direção, a pergunta que formulamos não diz respeito à oposição, mas a composição: que composições possíveis entre surdos e ouvintes? A colocação do problema nesses termos coloca no centro do debate a composição de um mundo comum, articulado a partir do encontro com a diferença no campo da surdez. Um mundo comum que não se tece como um universo, mas como pluriverso, atravessado por muitas versões da surdez. Este mundo comum e heterogêneo, como salienta Latour (2011) não é algo dado na partida. Não é um mundo unívoco, mas antes se constitui como um pluriverso, isto é, um mundo no qual múltiplas versões de escutar e não escutar vão sendo tecidas. A composição desse mundo comum jamais está dada de uma vez por todas, ela nos demanda trabalho, investimento para compor e articular elementos díspares e heterógenos. Na construção da pesquisa, tomamos a noção de pluriverso como operador que nos permite avançar na articulação entre surdos e ouvintes.

A aposta metodológica do trabalho consistiu em contar histórias situadas e localizadas (Haraway, 1995; Conti, 2015; Moraes \& Tsallis, 2016) de nossos encontros no campo da surdez. São histórias do cotidiano - aquelas nas quais ocorrem os encontros 
mistos (Martins, 2006) entre pessoas com as mais diversas condições auditivas - que construímos como campo. Contar histórias justamente para problematizar a história da oposição binária entre surdos e ouvintes que não cessa de se reiterar no senso comum. Contar histórias, povoar o mundo com múltiplas possibilidades de encontros entre surdos e ouvintes. Nosso objetivo é fazer proliferar as versões da surdez e da audição para compor um mundo comum: múltiplo e heterogêneo. Para isso, cabe não se posicionar em um ou outro lado do jogo binário, mas ir junto com as histórias que começam a emergir, borrando dicotomias, indo na direção da tentativa de forjar um mundo comum. "[Na] certeza de que esse mundo comum deve ser construído a partir de partes totalmente heterogêneas que nunca formarão um todo, mas, na melhor das hipóteses, um material composto frágil, revisável e diverso." (Latour, 2010, p. 474, tradução livre).

As histórias narradas aqui, sinalizadas no texto em itálico, são frutos do registro de campo da prática profissional cotidiana com pessoas surdas tanto em instituição educacional, quanto fora delas. Achamos que teria sido interessante poder acordar com nossas parcerias e com as pessoas que protagonizaram as histórias o uso de seus nomes próprios. $\mathrm{Na}$ impossibilidade de fazê-lo, usamos nomes fictícios escolhidos a partir da música Gente, do Caetano Veloso (1977). O projeto em questão foi aprovado pelo Comitê de Ética em Pesquisa com Seres Humanos, sob o número CAEE 65889817.6.0000.5243.

Os leitores irão se deparar ao longo do texto ora com o uso do pronome na primeira pessoa do singular, ora na primeira do plural, expressão da relação que nos vincula como autoras desse trabalho. Em alguns momentos, o percurso foi realizado apenas por uma de nós, em outros estivemos juntas nas discussões e nas formulações teórico-práticas que compuseram a pesquisa. É essa modulação que estabeleceu a nossa relação de orientanda e orientadora e que está também marcada nesse artigo. 


\section{Caetano: sobre composições}

Após um atendimento no âmbito da psicologia escolar, Zezé perguntou quando eu iria montar o grupo de social. Que grupo? - O grupo de social que você falou que ia montar! Eu não me lembro de ter dito isso, mas soa interessante montar um grupo de jovens para debater questões diversas. Perguntei: Um grupo para discutir o que? Para pensar o futuro, respondeu ela. - Um grupo semanal, por exemplo, toda $5^{\underline{a}}$ feira se encontrar de $13 \mathrm{~h}$ às $14 \mathrm{~h}$ ?. - Isso, mas pode ser $3^{\text {a }}$ feira? Vou chamar tais e tais alunos e começamos semana que vem, ok? Ok, grupo montado, então!

Conforme nos encontrávamos, diversos temas iam sendo discutidos. Surgiu, um dia, o tema da família - discutimos como era a relação familiar de cada um, como se sentiam com relação a isso, como melhorar relações. Nesse ínterim, Caetano me pediu: você pode conversar com minha família? Queria que você conversasse com ela. Me dou super bem com minha família, minha mãe deixa eu fazer várias coisas, mas tem umas coisas que ela não entende. Por exemplo, eu queria viajar para um evento com amigos daqui e um professor, e ela não está deixando. Acho que ela não entende muito sobre ser surdo, parece que ela me trata um pouco diferente por causa disso.

Convidei a família dele para uma conversa, sua mãe e seu pai vieram. Caetano sinalizou sobre como estava se sentindo, disse que amava os pais, que não estava ali para fazer reclamações, mas gostaria de colocar algumas coisas. Os pais me contaram sobre o irmão de Caetano, que morreu há alguns anos com uma doença súbita, e como isso fazia a mãe se preocupar em excesso com seus outros dois filhos. Não era só porque o Caetano era surdo, havia também esse atravessamento. Mas no desenrolar da conversa foi possível entender que tinha alguma coisa a ver com o fato do Caetano ser surdo, também.

No atendimento tinha duas intérpretes, e eu sabia que uma delas era CODA (do inglês children of deaf adults, e em português, filha ouvinte de pais surdos). Normalmente o intérprete não deve intervir nos atendimentos, ainda assim eu perguntei para ela: 
Leilinha, seus pais são surdos e tiveram duas filhas, né? Como era a rotina de vocês? Como eles faziam para resolver as coisas do dia a dia? Conta um pouco para a gente. E a intérprete começou a contar histórias da sua família, de seus pais, do cotidiano deles. E com isso, fomos desconstruindo um pouco a ideia de surdo que os pais de Caetano carregavam.

Levei também um vídeo (É Libras, 2017) onde dois amigos - um surdo e uma ouvinte - falavam sobre a experiência dele, incentivando familiares de surdos a aprender Libras. Ao final do atendimento, todos pareciam se sentir bem. (Trecho do diário de campo da pesquisadora).

O encontro com Caetano e sua família é marcado pela heterogeneidade que compunha a cena: as línguas, as intérpretes, o aluno surdo, a família ouvinte, a psicóloga ouvinte, o filho-irmão que a família sente falta, o computador e o vídeo de jovens com outras experiências, a existência anterior de um grupo e um vínculo - para nomear algumas.

Frente à heterogeneidade do encontro como compor o mundo comum? Latour (2011) nos dá uma pista quando diz: "não há nenhum outro meio de compor o mundo comum, sabemos bem, do que o recompondo, do que retomando desde o início o movimento de composição." (s/p). Como pensar, então, nas possibilidades de compor e recompor o mundo?

Naquele atendimento criamos possibilidade para que cada um de nós se deslocasse sutil ou não tão sutilmente. No acolhimento das histórias que aquela família trazia, saí do lugar de psicóloga especialista detentora do saber para construir com eles outros modos de se relacionarem. Lançando mão de composições anteriores, pude convidar a intérprete a sair de seu lugar de mediadora linguística para contar suas histórias, e ao aceitar ela se deslocou também, trazendo com seu corpo e sua vida características de um solo da surdez que ela conhecia e disponibilizando-se para a troca com aquela família que ela não conhecia. Ao escutar o filho através da tradução de sua língua 
para o português, a família também estremeceu, pois apesar de terem seus meios próprios de comunicação familiar, havia ali naquela fala nuances que só com a presença do intérprete e uma profundidade da língua puderam entender.

Que beleza de história! Que final feliz! Então agora Caetano pode viajar com os amigos? A família toda se entende? Os pais começaram a fazer curso de Libras? Tudo resolvido? Esse negócio de composição é bom mesmo!

Mesmo que a palavra 'composição' seja um tanto longa e aberta, o que é bom é que ela enfatiza que as coisas devem ser colocadas juntas (do latim componere), enquanto mantendo suas heterogeneidades. Além disso, está conectada com compostura; tem raízes claras na arte (...); não está muito longe de 'comprometer' e 'comprometedor', mantendo um certo sabor diplomático e prudencial. Falando em sabor, ela traz consigo o cheiro pungente mas ecologicamente correto de 'composto', ele próprio devido à ativa 'decomposição' de muitos agentes invisíveis... Acima de tudo, uma composição pode falhar (...). Ela, portanto, desvia a atenção da irrelevante diferença entre o que é construído e o que não é construído, em direção à diferença crucial entre o que é bem ou mal construído, bem ou mal composto [(...) A energia usada para responder à questão ‘é construído ou é verdade?’ não deixa vigor para desdobrar a complexa casuística que responde, local e praticamente, à pergunta 'está bem ou mal composto?' (...)]. O que está para ser composto pode, a qualquer momento, ser decomposto. (Latour, 2010, p. 473-474, tradução livre, grifos do autor).

Volta e meia Caetano me relembra daquele nosso encontro. Se surge algum assunto sobre família, ele diz: - você sabe né, você já conversou com minha família; - você já conhece minha família; - ah, obrigada porque aquele dia você conversou com minha família. Um dia perguntei a ele: Mas e aí, mudou? Tá fazendo alguma diferença? E ele 
respondeu: Ah, não. Não mudou muito, não. Mas foi importante, a conversa (Trecho do diário de campo da pesquisadora).

Composição não trata de finais felizes para sempre. De fato, não se trata de final algum. A aposta é na possibilidade de construção de um presente espesso em significados e corpos que, ainda que frágil e passível de decomposição, faz-se potente para a construção de um mundo comum.

\section{Festa sencity e a experiência da multissensorialidade}

Fui, e levei minha prima, à festa de encerramento do V ENAC (5ํㅡㄴ Encontro Nacional de Acessibilidade Cultural, realizado pela UFRJ). O espaço estava dividido em vários ambientes. No salão principal havia a pista de dança: um palco à frente e um tablado de madeira ao fundo.

No palco, estavam os DJs, disc-jockeys, entremeando as apresentações musicais: bandas, cantores solo, grupos de percussão... todos acompanhados por intérpretes musicais que transmitiam a música através de sinais e movimentos corporais muito diferentes e belos. No canto direito, estavam aroma-jockeys com béqueres e tubos de ensaio, lembrando um laboratório de química. Daquele mini-lab, envolto em fumaça de gelo seco, saiam mixagens de aromas de alguma maneira sincronizados com as músicas. Além das luzes, um VJ - video-jockey - projetava imagens no telão ao fundo do palco. Quando cansávamos podíamos relaxar em uma sala cheia de espuma e isopor espalhados pelo chão, onde havia também uma exposição de fotografias. Se batesse a fome, encontraríamos misturas inusitadas, que faziam nossa língua vibrar com a explosão de sabores. Mais outra sala fazia vezes de feira gastronômica, com pratos de países latino-americanos e africanos. Em certo momento, o salão quase lotado, e todos começamos a dançar em passinhos sincronizados, guiados por um grupo que estava lá na frente. E, surpreendentemente, para nós ouvintes, pudemos não apenas ouvir, mas sentir a música, dançando em cima do tablado de madeira que 
vibrava com as caixas de som, e essa vibração era conduzida através de nosso corpo, mostrando-nos outra forma de experimentar a música. Minha prima e eu estávamos perplexas sobre o quanto pudemos experimentar com todo o corpo naquele evento. Nunca havíamos sentido falta de nenhum desses aparatos, mas estar naquela festa multissensorial nos mostrou outro modo de habitar nossos corpos. (Trecho do diário de campo da pesquisadora).

A festa produziu um deslocamento. Curiosamente ela foi criada com a surdez (sua primeira edição se chamava DeafValley), o que talvez tenha proporcionado a possibilidade de pensar a multissensorialidade. Talvez o mundo comum exista como mundo multissensorial, desafiando a centralidade de um sentido específico - seja da visão, seja da audição -, afirmando a potência da conexão dos sentidos para nós, surdos e ouvintes. Os desvios e inflexões a serem feitas para a composição do mundo conectam e articulam atores heterogêneos - trata-se de experimentarmos conexões inusitadas.

Permanecer com o problema requer fazer parentescos estranhos; isto é, nós convocamos uns aos outros em colaborações e combinações inesperadas, em pilhas de compostagem quente. Nós nos tornamos uns com os outros, ou não nos tornamos de jeito nenhum. (...) Sozinhos, em nossos separados tipos de especializações e experiências, sabemos muito e muito pouco, e por isso sucumbimos ao desespero ou à esperança, e nenhum dos dois é uma atitude sensata. Nem o desespero nem a esperança estão sintonizados com os sentidos, com a matéria consciente, com a semiótica material, com os terráqueos mortais em copresença espessa. (...) (Haraway, 2016, p. 4, tradução livre).

Concordamos com Haraway: só somos com o outro, não há escapatória - caso contrário, permanecemos os mesmos. É necessária a interpelação do outro para que possamos nos deslocar de nós mesmos e assim produzir outros conhecimentos, 
outras experiências, produzir novos mundos e novas maneiras de estar nesse mundo. Fazer parentescos estranhos, para que não saibamos nem demais nem de menos.

\section{Maurício: sobre parentescos estranhos}

Maurício, um amigo surdo, reclamava da sua experiência no banco: para iniciar uma conversa com a gerente, mostrou-Ihe um papel em que estava escrito que era surdo. Escrevera no papel sua dúvida e mostrou para ela. Na primeira vez que o leu,ela começou a responder oralmente. Ele interrompeu-a e apontou para o papel, para que Ihe respondesse por escrito. A gerente, sem graça, desculpou-se e escreveu a resposta no papel. Maurício leu calmamente e escreveu outra pergunta. A gerente, interessada, leu o papel e imediatamente começou a responder oralmente de novo. Não! - interrompeu Maurício - sou surdo!, lembrou a ela, e apontou novamente para o papel. A gerente, mais sem graça ainda, retomou a comunicação pela estratégia sugerida. Porém, durante toda conversa, ela realizava o mesmo movimento: lia o papel e respondia oralmente. Ele seguia na insistência de interrompê-la, lembrá-la que é surdo, e aguardar pacientemente (ou nem tanto) ela se envergonhar e retomar a comunicação pelo papel. (Trecho do diário de campo da pesquisadora).

Essa cena poderia ser lida como a manutenção de dois mundos. O surdo que não foi atendido como esperava, a ouvinte que insistia em se manter no seu lugar sem abraçar prontamente a estratégia proposta. Meu amigo contou-me em tom de reclamação. Eu mesma, em um primeiro momento, avaliei essa história desta maneira: tá vendo só? Olha aí a dificuldade de estar com o outro! Olha dois mundos existindo novamente!

Em um segundo olhar, permeado das novas companhias e reflexões de pesquisa, lembramos de Haraway, que nos convoca a compor não apenas com o que nos é familiar, mas a compor com o estranho. 
Fazer parentescos como parentescos estranhos em vez de, ou ao menos em adição aos, parentescos afins e familiares genealógicos e biogenéticos, é um problema de matéria importante para quem é realmente responsável. Quem vive e quem morre, e como, neste parentesco, e não naquele? De qual forma é essa relação de parentesco, onde e quem as suas linhas conectam e desconectam, e daí? O que deve ser cortado e o que deve ser amarrado se as multiespécies que florescem na terra, incluindo humanos e não-humanos em parentesco, quiserem ter uma chance? (Haraway, 2016, p. 2, tradução livre).

Para Maurício, o papel e a caneta não são parentescos estranhos para se comunicar tanto que ele os propôs como mediadores. Para a gerente, caneta e papel não são objetos estranhos. Mas naquele encontro, convocam a parentescos estranhos, frente ao qual ela não sabe como agir, se perde, retoma, se envergonha. Mas sustenta, persiste ali. Coloca-se em uma posição responsável, de response-ability (Haraway, 2011): não se retira da relação à qual é convocada e que estabelece momentaneamente com o surdo, com a caneta e com o papel. Poderia ter ido embora, se negado a atendê-lo, solicitado que outra pessoa continuasse o atendimento, mas não o fez, mesmo com todo incômodo sublinhado na história.

Tal reflexão nos convoca a pensar quais são as conexões que se estabelecem entre surdos e ouvintes, para além das diferenças. Ou melhor, sustentando as diferenças, e que essas não impossibilitem a relação de parentesco. Pode nos mostrar também o quanto tais relações não se limitam aos humanos surdos e ouvintes, mas também são estabelecidas com os não-humanos nesses pluriversos.

Eu, como ouvinte no campo da surdez, sinto-me convocada a este processo de composição. Preciso sair de um lugar de conforto, me deslocar dos meus saberes e me disponibilizar para o encontro com as pessoas surdas em um funcionamento bem diferente do meu - pela língua, pela maneira de organizar o pensamento, pela forma mais direta de tratar os assuntos (que às vezes parece rude para nós, ouvintes) -, pois 
caso não o fizesse, me manteria nas mesmas referências, não teria muita possibilidade de troca com os surdos, não conseguiria compor um comum. Ficaria no lugar, talvez, da pessoa que quer normalizar o outro, querendo que o surdo se ajuste e se adapte ao meu modo (ouvinte) de fazer as coisas.

Trata-se de fazer desse um presente espesso, ficar com o problema, ser inventivo, compor a cada situação novas conexões, emaranhadas àquelas que já nos compõem, para que assim possamos existir nesse mundo comum, a partir da heterogeneidade. Ainda assim, no campo da surdez a ideia de dois mundos é muito reafirmada. Enxergá-lo em sua pluralidade e fazê-lo existir na composição do comum é exercício constante.

A tarefa é fazer parentescos em linhas de conexão inventiva como uma prática de aprender a viver e morrer bem uns com os outros em um presente espesso. A nossa tarefa é criar problemas, estimular resposta potente a eventos devastadores, bem como acalmar águas turbulentas e reconstruir locais tranquilos. (Haraway, 2016, p.1, tradução livre).

\section{Pluriverso}

O esforço inicial da pesquisa era para pensar, se não em dois mundos, em um mundo comum, passível de habitação por surdos e ouvintes. Mas o processo de pesquisa nos fez refletir sobre a não existência desse mundo comum a priori. Assim como não há surdos a priori. O que nos levou a pensar que também não há ouvintes a priori. Não há um mundo a ser desvelado. Não vamos andar por aí e esbarrar em um espaço-mundo - ou transformar um dia o nosso mundo em um lugar - em que se conviva sem que as diferenças importem. "O pluralismo está conosco para sempre. Pluralismo de culturas, sim, das ideologias, das opiniões, dos sentimentos, das religiões, das paixões, mas também pluralismo das naturezas, das relações com os mundos vivos, materiais e também com os mundos espirituais." (Latour, 2011, s/p). 
Não se trata de apagar as diferenças em nós. Para além das ideias-identidades estanques de surdo e ouvinte, queremos poder diferir, produzir diferenciação inclusive de nós mesmos. E queremos um mundo em que a diferença interesse. Sendo assim, ainda que consigamos compor este mundo comum, ele não será um universo, mas um pluriverso (James citado por Latour, 2010, 2011).

Nenhum acordo possível sobre o que compõe o mundo, sobre os seres que o habitam, que o habitaram, que devem habitá-lo. Os desacordos não são superficiais, passageiros, devidos a simples erros de pedagogia ou de comunicação, mas fundamentais. Eles ferem as culturas e as naturezas, as metafísicas práticas, vividas, vivas, ativas. (...) Se nós colocamos de lado o que nos separa, não há nada que nos resta para colocar em comum. O pluralismo fere muito profundamente. O universo é um pluriverso (James). (Latour, 2011, $s / p)$.

A partir do contato com essa perspectiva, podemos revisitar as histórias presentes neste artigo, revisitar o campo, vislumbrando-o como pluriverso. Tal noção não fala de uma situação específica, mas de um modo de ver e viver o campo (a vida) com outro posicionamento. Possibilita inventar diferentes lentes.

\section{Gilberto: sobre línguas e traduções}

Em uma aula do penúltimo semestre, o professor surdo Gilberto pede para a turma evitar o português oral. Alunos ouvintes prestes a nos formar em Libras, precisamos aprender a entender e nos expressar com mais fluidez. A turma reclama que ele sinaliza muito rápido e perguntam se ao dar aula para os alunos surdos adolescentes ele sinaliza com a mesma rapidez. Gilberto responde que sinaliza muito mais rápido, que ali na nossa aula ele sinalizava infinitamente mais devagar do que algum dia sinalizaria com outro surdo. Que nossa Libras é, para um surdo, como um ouvinte falando beeeeeem devagar (e imita, desta vez oralizando, a fala de um ouvinte muito 
arrastada) e por isso o surdo muitas vezes não teria paciência para conversar conosco.

Como aprimorar nossas habilidades em Libras?, perguntam os alunos. Em contato com os surdos, responde o professor. Os alunos queriam muito ter amigos surdos, mas não sabiam onde encontrá-los. Gilberto responde ironicamente, sinalizando a ação de enlaçar, como em um rodeio.

Será que frequentar uma associação de surdos, sabidamente espaço de convivência e lazer entre os surdos, possibilitaria este contato? Não, responde Gilberto, quando um ouvinte com nossa pouca fluência está em um evento ou associação de surdos, um fenômeno acontece: o surdo que conversar com ele irá fazê-lo prestando atenção ao grupo de surdos ao lado, babando de vontade de estar entre seus pares, e em pouco tempo pedirá licença ao ouvinte. Em uma situação com mais de um ouvinte, rapidamente haveriam dois grupos formados: os surdos de um lado e os ouvintes de outro.

Gilberto continua: o surdo fica de segunda a sexta entre os ouvintes, sem muito contato ou conversa com ninguém, meio paradão ali. Fica só sonhando com o sábado e domingo, quando finalmente encontrará surdos para se comunicar em Libras, dividir não só uma língua, mas uma cultura, uma visão de mundo. Vai querer fofocar, falar da novela, conversar entre surdos, e não com ouvintes. (Trecho do diário de campo da pesquisadora).

Às vezes nos pegamos na insistência de encarar a diferença unicamente como um desacordo a ser retratado. No campo da surdez como minoria linguística vemos isso se operar com a língua e a acessibilidade linguística.

Há um discurso muito proliferado que associa acessibilidade e inclusão social à Libras. É muito presente a ideia de que todos precisam aprender Libras, e assim a inclusão social aconteceria. Então, na escola oferecemos oficina de Libras para as famílias de alunos; o curso de Libras oferecido pela instituição tem vagas prioritárias para 
funcionários de serviços públicos; os trabalhos que encontramos sobre a surdez relatos de experiência, pesquisas científicas, metodologias de ensino - muitas vezes colocam a centralidade na Libras; na Lei afirma-se a necessidade das instituições públicas terem um intérprete ou um funcionário que saiba Libras; a acessibilidade nas instituições religiosas conecta-se diretamente com a presença de um intérprete.

Há uma importância imensa no aprendizado e disseminação da língua de sinais. Aprendi a Libras, primeiro como compromisso assumido no concurso para o instituto e depois por desejar estar e participar do que eu, a princípio, via como universo da surdez. Encantei-me com as línguas de sinais e busquei aprofundar-me, adquirindo maior fluência. No processo do Mestrado, a fluência na língua atravessou meu percurso diversas vezes, tanto no modo como me relacionava com o campo quanto na maneira de organizar pensamento e palavras na escrita. No âmbito do trabalho na instituição, o vínculo com profissionais e alunos surdos estreita-se por meio do domínio da Libras. No encontro com a surdez nos diferentes espaços, a língua vira ponte para contato e trocas diversificadas.

A história de Gilberto nos mostra o interesse dos alunos ouvintes em ultrapassarem a barreira linguística, em terem mais contato com surdos. Mas ao centralizarmo-nos na língua, surdos e ouvintes distanciam-se. Nesta história, ouvintes ficam à caça de um amigo surdo, surdos ficam a semana inteira sem ter com quem conversar.

Existem perigos e limitações em centralizarmo-nos na Libras para pensar o campo da surdez. Quando fazemos isso, ignoramos toda a população surda não usuária da língua de sinais. E mesmo os surdos usuários da língua de sinais ficariam presos e homogeneizados sob essa marca, apagando suas singularidades. A língua vem soberana e tudo mais vem a reboque. Cria-se uma expectativa de que falar a mesma língua resolverá os problemas, quando - como qualquer outro idioma - falar a mesma língua facilita, mas não garante a comunicação. Para além da língua, é crucial a disponibilidade que apresentamos para estar com o outro. 
Gilberto, na história, sinaliza que as diferenças não serão apaziguadas ao sabermos uma língua em comum e que tampouco uma amizade se forma apenas porque uma pessoa quer - e compara esse pedido à ação de catar no laço os surdos. Ao revisitar essa história, percebo como o pedido dos ouvintes de ter um amigo surdo soa mesmo colonizador.

Isso não significa abrirmos mão da língua, ou mesmo do intérprete. Mas precisamos pensá-los não apenas como ponte que une dois mundos e nem como única solução em meio à tantos outros deslocamentos que podemos e precisamos operar.

No processo da pesquisa e na relação com as línguas, encontramos na tradução uma pista para a composição do comum, como uma maneira de nos relacionarmos com o campo, não apenas como ponte, como intermediária entre polos distintos, mas como postura ética para nos relacionarmos com a diferença, como possibilidade de deslocamento.

Tema e versão são modos de pensar a tradução que Vinciane Despret (2012) nos traz. Segundo a autora, a tradução por tema busca uma significação única, objetiva fidelidade ao texto original, uma tentativa de "passar de um mundo ao outro sem sobressalto, com a condição de fazê-lo em linha reta, sem deformação." (Despret, 2012, p. 233).

A tradução por versões, de outro modo, assume que há escolhas na passagem de uma língua a outra, que irão produzir sentidos a partir de e considerando as diferenças. “(...) Ao contrário do tema, estas escolhas vão repousar sobre o princípio da multiplicidade de sentidos possíveis, na gama dos possíveis que recobrem as 'homonímias': um mesmo termo pode abrir uma quantidade de significações e fazer divergir os sentidos." (Despret, 2012, p. 233).

Nas versões produzidas pela tradução no encontro com o surdo, multiplicidades aparecem, levando à ampliação de produção de sentidos. E assim sendo, é 
permanente o risco de que as versões das traduções produzam equivocações e descompassos.

Ainda com pouco domínio da língua de sinais, conversava com uma criança surda de 8 anos, que me contou uma coisa surpreendente. Fiz o sinal de mentira!, com cara de espanto (ou pelo menos achei que minha cara era de espanto), como sinônimo de não acredito! Mas minha tentativa de traduzir do meu português para a Libras da criança não deu muito certo: ela interpretou meus sinais como uma ofensa e começou a esbravejar com as mãos, com raiva de mim por tê-la chamado de mentirosa. Fiquei envergonhada, e por um tempo processava a cena em minha cabeça, experimentando outros sinais possíveis para usar em situação semelhante.

Algum tempo depois, já com maior fluência, vivi uma revanche da língua, onde apareceram mal-entendidos na tradução, desta vez da Libras para o português. Estava batendo papo com dois surdos, fazendo sala, enquanto esperávamos a tradutora-intérprete de língua de sinais e português (TILSP) para acompanhar o atendimento, que seria realizado pela assistente social. A intérprete chegou e eu me retirei. Me arrumava para ir embora, quando quase na porta um dos surdos me chamou e fez em sequencia 3 sinais: bandido; folgado; moleza. Eu disse para a intérprete, em português e em Libras: Ué, sério? Não entendi! Estaria aquele cara me xingando, na cara de pau? Me senti ofendida. Antes que a TILSP traduzisse, o próprio surdo me explicou: Essa hora, já indo embora! Trabalho moleza!

Lembrei-me da criança ofendida e da pouca possibilidade naquele encontro, de multiplicar as versões. Já neste, foi possível sustentar os descompassos da língua, e dar passagens às equivocações para que outras coisas se produzissem. Deste modo, pude entender que no contexto o sinal de bandido poderia ter sido traduzido também como um sinônimo: vagabundo. Só que esta palavra em português é muito forte, é um xingamento. Apesar de perplexa, tentei explicar-lhe meus horários. Ele continuou repetindo o sinal, e rindo. Entendi, então, que em Libras a palavra talvez não tivesse o 
mesmo peso, e ali era uma provocação, uma brincadeira. (Trecho do diário de campo da pesquisadora).

Enquanto na tradução por tema buscar-se-ia corrigir esses descompassos buscando fidelidade ao texto original, na tradução por versões esses descompassos reverberam, dando passagem a outras histórias possíveis.

Traduzir, segundo o modo da versão, conduz, portanto, a multiplicar as definições e os possíveis, a tornar perceptíveis mais experiências, a cultivar equívocos, em suma, fazer proliferar histórias que nos constituem como seres sensíveis, ligados aos outros, e afetados. Traduzir não é interpretar, é experimentar equivocações. (Despret, 2012, p. 240)

Neste caminhar, a tradução foi se apresentando como possibilidade de transitar no pluriverso da surdez. De que maneira a tradução como equivocações pode se configurar como uma ética no encontro com surdos e com a surdez?

\section{Travessias: sobre invenções e possibilidades de deslocamentos}

João, aluno surdo, veio me contar (em Libras) de um flerte ao comprar "produtos que o deixam mais cheiroso" (sic). Mostra como estava paquerando uma vendedora (ouvinte), monta a cena com gestos incomuns, e ao final, justificando-os, me diz: - Em Libras, namorar (faz o sinal de namorar). Em português, (faz um gesto para namorar beijo na mão - e identifica isso como língua portuguesa). - Em Libras, casar (faz o sinal de casar). Em português, (faz um gesto para casar - aponta dedo anular no local da aliança - e identifica isso como língua portuguesa). (Trecho do diário de campo da pesquisadora).

A tradução como equivocação envolve invenção de sentidos. Convoca a deformações para que, no encontro, significados outros sejam produzidos - um mundo comum possa temporariamente emergir. Faz-se necessário torcer os sentidos tanto da língua 
de origem quanto da língua de chegada, de modo que vamos até o outro e trazemos o outro até nós. Para além de comunicar, trata-se de criar modos de estar juntos.

Há, na dupla impossibilidade de tradução, a meu ver, a afirmação radical de uma possibilidade: a da fabulação, a da invenção na língua de chegada de algum sentido não para o que o outro disse precisa e justamente, mas para o quê, na minha língua preciso inventar, o quê na minha língua preciso refazer, mover para lidar com aquilo que vem do outro, do encontro. (Moraes, 2017).

A tradução aqui transmuta-se em travessia, que nos conduz não como ponte fixa de um ponto a outro, de uma língua a outra, de um mundo ao outro (o que reafirmaria a ideia de dois mundos). Mas como caminhos possíveis a se inventar nos encontros, caminhos que podem fazer fechar significados, podem segregar, mas podem também operar em aberturas para inventar outros encontros, para se habitar pluriversos.

João nos mostra que fez uma operação na língua dele - transformou os sinais para que a sua paquera pudesse compreendê-lo. E fez uma operação no português também: trouxe uma dimensão de sinalização para uma língua que, no dia a dia, não diríamos sinalizada. João marcou o português, mostrando-nos que não só a Libras, mas também nossa língua portuguesa, hegemônica, tem suas marcas. João provocou, assim, deslocamentos e invenção de sentidos nas duas línguas, na Libras e no português.

Uma boa tradução, escreve ainda Viveiros de Castro, é aquela que autoriza os conceitos dos outros a deformar e a subverter estas caixas de ferramentas do tradutor, de forma que a linguagem de origem possa ser traduzida na nova'. Traduzir não é explicar, ainda menos explicar o mundo dos outros, é colocar o que nós pensamos ou do que temos experiência à prova do que os outros pensam ou têm experiência. (...) (Despret, 2012, 236-237).

Pensar a tradução como travessia, parece-nos que traz tanto a dimensão do encontro como a dimensão das versões e das equivocações - de maneira que essas 
equivocações não se dão apenas na língua de chegada, mas que nesse processo a língua de origem também é interpelada.

\section{Composições possíveis: à guisa de conclusão}

Os encontros com a surdez, que se fizeram histórias, que por sua vez se fizeram campo de pesquisa, nos convocaram e nos desestabilizaram, auxiliaram a construir novas lentes, provisórias sempre, para olhar para o campo da surdez. E novo corpo para habitá-lo. As dicotomias estão postas, e no exercício de tensioná-las nos deparamos com a importância (queria dizer necessidade) da construção de um comum.

Compor um comum não é abrir mão de si e encontrar o que é igual entre você e o outro, em uma busca de identidade, mas entender que é a partir das diferenças (das heterogeneidades) que será possível criar uma composição - provisória, local, situada no tempo e no espaço.

Habitar o mundo comum convoca à produção de sentidos temporários, de travessia que borra chegada e partida, não apagando as diferenças, mas fazendo-as existir como reinvenção, como pluriverso.

No encontro com o outro precisamos nos deslocar se quisermos produzir algo diferente. Concluímos que um modo de habitar esse pluriverso da surdez na direção da construção do comum é buscando produzir composições. E para a composição, precisamos nos misturar, desmanchar um pouco do que há em nós, borrar com um pouco do que há no outro. Isso não significa buscar uma igualdade, apagando nossas marcas e nossas diferenças. E sim entender que com a diferença é que é possível compor.

A composição é frágil, provisória e potente. Ela pode acontecer na produção de um presente espesso. Uma forma de construir um mundo comum, temporária, pois que sempre será momentânea, e se dará em um trabalho sem fim. Que demanda 
disponibilidade e presença. Experimentações são necessárias, outras histórias precisam ser produzidas e contadas - nesse sentido, um presente espesso também, onde se dê passagem para outras materialidades e outros significados.

Posicionando-nos enquanto ouvintes no encontro com a surdez, importa que nos deixemos estremecer, fazer aparecer nossas marcas, nossa hegemonia, e buscar, na composição com o surdo e com a surdez, um desmanchar na direção de aberturas e criações abarcando nossas diferenças.

Tarefas nada fáceis, que demandam continuidade, que se refazem a cada instante. Que tenhamos a coragem e a disponibilidade para habitar esse pluriverso, na construção de mundos comuns.

\section{Referências}

Conti, J. (2015). Margens entre pesquisar e acompanhar: o que fazemos existir com as histórias que contamos? (Dissertação de Mestrado, Universidade Federal Fluminense, Niterói). $\quad$ Recuperado de https://app.uff.br/slab/uploads/2015_d_Josselem.pdf

Despret, V. (2012). V comme versions. Em V. Despret, Que diraient les animaux, si... on leur posait les bonnes questions? (pp. 231-242). Paris: La Découverte / Les Empêcheurs de Penseren Rond.

É Libras. (2017, 5 de março). Comunicação com a família ouvinte [Arquivo de vídeo]. Recuperado de https://www.youtube.com/watch?v=K_NL64TzV8

Haraway, D. (1995). Saberes Localizados: a questão da ciência para o feminismo e o privilégio da perspectiva parcial. Cadernos Pagu, O(5), 7-41. Recuperado de https://periodicos.sbu.unicamp.br/ojs/index.php/cadpagu/article/view/1773/1828

Haraway, D. (2011). A partilha do sofrimento: relações instrumentais entre animais de laboratório e sua gente. Horizontes Antropológicos, 17(35), 27-64. https://dx.doi.org/10.1590/S0104-71832011000100002 
Haraway, D. (2016). Introduction. Em D. Haraway, Staying with the trouble: making kin in the Chthulucene (pp. 1-8). Durham: Duke University Press.

Latour, B. (2010). An attempt at a "Compositionist Manifesto". New Literary History, 41, 471-490. Recuperado de http://www.bruno-latour.fr/sites/default/files/120-NLHfinalpdf.pdf

Latour, B. (2011). Não há mundo comum: é preciso compô-lo [Publicação em um blog]. Recuperado de https://politicadasensibilidade.wordpress.com/2017/01/16/nao-ha-mundocomum-e-preciso-compo-lo-bruno-latour/

Martins, B. S. (2006). E se eu fosse cego. Porto: Afrontamento.

Moraes, M. (2017). Narrativas e traduções do campo de pesquisa: pesquisarCOM pessoas cegas e com baixa visão. Em Política de Pesquisa. Palestra apresentada no evento do Instituto de Psicologia realizado na Universidade Federal Fluminense, Niterói, Rio de Janeiro, Brasil.

Moraes, M., \& Tallis, A. (2016). Contar histórias, povoar o mundo: a escrita acadêmica e o feminino na ciência. Polis e Psique, 6(1), 39-50. https://doi.org/10.22456/2238-152X.61380

Veloso, C. (1977). Gente. [Gravado por C. Veloso]. Em Bicho [LP]. Rio de Janeiro: CBD Phonogram.

\section{Declaração do contributo dos autores}

LLS e MM contribuíram no desenho e implementação da investigação. LLS realizou o trabalho de campo. LLS e MM analisaram os dados e discutiram os resultados. Todas as autoras produziram o manuscrito e contribuíram para a versão final do mesmo. 
Formato de citación

Lima da Silva, L. \& Moraes, M. (2019). Composições possíveis: travessias no pluriverso dos encontros com a surdez. Psicología, Conocimiento y Sociedad, 9(2), 221-243. doi: http://dx.doi.org/10.26864/PCS.v9.n2.9 